\title{
3
}

\section{Regulation of the Barbados International Business and Financial Services Sector}

\section{I Regulation and supervision of the IFS sector pre-1998}

Barbados is characterised as a low-tax jurisdiction, with a long-standing reputation for a sound legal framework and high regulatory and supervisory standards. The success achieved to date in attracting international business is reflective of the extensive treaty network of double taxation agreements and bilateral investment treaties with several countries, including most importantly the United States and Canada, which encourage transparency and the establishment of a commercial presence. In addition, the industry benefits from effective co-operation between government and the private sector on legislative reforms and promotion. As such, legislative amendments have been implemented in response to changes in the international business environment in an effort to capitalise on new opportunities. A legal separation between the international business services industry and the onshore financial sector is maintained in Barbados, and any activity between the two requires the special permission of the Minister of Finance. This effectively limits the potential for the transmission of contagion effects between the international business and the domestic financial sectors.

As indicated above, Barbados' IFS industry comprises international business companies (IBCs), international (offshore) banks (OSBs), exempt insurance companies (EICs), exempt insurance management companies (EIMCs), exempt insurance holding companies (EIHCs) and societies with restricted liability (SRLs). Regulatory and supervisory oversight of the various international business entities is shared by various agencies. The Central Bank of Barbados regulates and supervises the operations of OSBs, the International Business Unit of the Ministry of Industry and International Business oversees the operations of IBCs and SRLs, and the Office of the Supervisor of Insurance and Pensions has regulatory and supervisory oversight over EICs, EIMCs and EIHCs. In addition, the Barbados Investment and Development Corporation (BIDC), a government investment agency, and Barbados International Business Association (BIBA), the private sector representative of the companies engaged in international business, support the Government in the marketing and promotion of international business activity in Barbados. It noteworthy that the Central Bank of Barbados and the Office of the Supervisor of Insurance have regulatory and supervisory oversight for both domestic and offshore entities in their respective areas. 
Pre-2002 offshore banking activity in Barbados was conducted under the auspices of the 1979 Offshore Banking Act. Some offshore banks are subsidiaries of a parent bank, with customers generally afforded the full range of services of the parent. The Act specified that only non-residents are eligible to hold bank accounts with an offshore bank or trust company, or to hold investments, accounts and conduct their transactions in global currencies. The Act provided for offshore banks to benefit from a similar range of fiscal incentives granted to IBCs, including the taxation of profits on a sliding scale at rates of 1 per cent to 2.5 per cent, no direct or capital gains tax on profits and exemption from exchange control and payment of import and other duties.

Offshore banks domiciled in Barbados conduct a wide range of activities within the banking and wider financial services fields. These include wealth management (primarily the formation and administration of trusts), investment banking, retail banking in foreign currencies and corporate and trade financing through the issue of international stocks and bonds, acquisitions and mergers. These entities are licensed and supervised by the Central Bank of Barbados in keeping with international best practices. Licensing, due diligence and prudential requirements are rigorous and the degree of regulation and supervision of financial institutions is high. Risks for depositors are, to a large extent, contained by restricting the acceptance of third party deposits to those offshore banks that are owned by foreign banks.

The Exempt Insurance Act Cap. 308A, was designed to allow Barbados to develop as a meaningful alternative to Bermuda for international insurance purposes, particularly captive insurance companies. Exempt insurance companies are licensed, regulated and supervised by the Supervisor of Insurance and Pensions within the Ministry of Finance in keeping with international standards. Under the Exempt Insurance Act Cap. 308A, companies pay no tax on their income for the first 15 years, with a 2 per cent rate, to a maximum of only $\mathrm{Bds} \$ 5,000$, thereafter. They are also exempt from withholding tax.

\subsection{Emergence and evolution of the post- 1998 regulatory regime for IFS}

There have been considerable external pressures for strengthening IFS regulation and supervision. The requirement to co-operate with the OECD in the highly contentious areas of information exchange, transparency and ring-fencing has been challenging. Barbados is well known as a 'clean', highly reputable jurisdiction that co-operates fully with international tax authorities and regulatory agencies. It is noteworthy that Barbados was not listed as one of the countries on the 2000 Financial Action Task Force (FATF) list of non-cooperative countries ${ }^{1}$ with 'detrimental practices that seriously and unjustifiably hamper the fight against money laundering'. Therefore, there was little concern about the greater exchange of information for criminal and civil tax inquiries, more extensive availability of beneficial ownership and trust information, or the higher degree of auditing and filing requirements, which formed part of the Harmful Taxation Debate. The tax treaties between Barbados and other countries contain provisions that 
facilitate such queries. The principle contacts for information exchange in Barbados are the Inland Revenue Department, the Supervisor of Insurance and the Central Bank of Barbados.

There were, however, some additional reporting and due diligence costs which resulted from Barbados' enhanced AML/CFT requirements. Firms in the accounting and auditing field have also cautioned that while clients are aware of the extensive due diligence undertaken in Barbados, there is likely to be some disquiet if private information is required to be made available for public inspection.

According to an IMF report in 2003, Barbados has worked diligently to develop an effective regime for anti-money laundering and combating the financing of terrorism. The Money Laundering (Prevention and Control) Act was enacted in 1998 and amended in 2002, the Anti-Terrorism Act was enacted in 2002, the Mutual Assistance in Criminal Matters Act (1993) was amended in 2001 and Anti-Money Laundering Guidelines, in keeping with FATF recommendations, have been issued to all financial services providers. The institutional structure was also strengthened in 2000 with the establishment of the Anti-Money Laundering Authority (AMLA), which is charged with ensuring compliance of AML/CFT requirements by all financial institutions. The Authority is well organised and functions through its supervisory board, which includes representatives from the Commissioner of Police, Inland Revenue, Customs authority, Supervisor of Insurance, Corporate Affairs and Intellectual Property Office, Central Bank and the Solicitor General's Office. The Financial Intelligence Unit (FIU), which was also established in 2000, conducts day-to-day activities of the AMLA: namely, receiving, analysing and disseminating pertinent financial information and intelligence and investigating suspicious transactions. The FIU meets the Egmont Group's definition and Barbados was admitted to Egmont membership in June 2002 2 . The Unit works closely with the supervisory authorities of the various types of financial institutions in monitoring compliance with AML/CFT requirements.

Furthermore, Barbados ${ }^{3}$ has demonstrated its commitment to AML/CFT through it membership and active participation in the Caribbean Financial Action Task Force (CFATF). This is an organisation of 30 states of the Caribbean Basin, which have agreed to implement common countermeasures to address the problem of criminal money laundering and the financing of terrorism. It was established as the result of meetings convened in Aruba in May 1990 and Jamaica in November 1992, with the main objective of achieving effective implementation of and compliance with its recommendations to prevent and control money laundering and to combat the financing of terrorism. The Secretariat of the CFATF has been established as a mechanism to monitor and encourage progress to ensure full implementation of the Kingston Ministerial Declaration ${ }^{4}$ and works closely with the Co-operating and Supporting Nations (the Governments of Canada, the Kingdom of the Netherlands, France the United Kingdom and the United States of America), which are all members of the Financial Action Task Force on Money Laundering and the International Financial Institutions. 
An AML/CFT supervision programme for offshore banking is in place. The Central Bank conducts off-site compliance reviews and has also implemented an on-site inspection programme.

The Financial System Stability Assessment (FSSA) report for Barbados (2003) confirmed the extent to which international standards and codes are observed by the financial sector. Detailed assessments of the following were carried out:

- The Basle Core Principles for Effective Banking Supervision

- The International Organization of Securities Commissions - Objectives and Principles of Securities Regulation

- The Committee on Payment and Settlement Systems - Core Principles for Systemically Important Payment Systems

- The International Association of Insurance Supervisors - Insurance Supervisory Principles

- The IMF's Code of Good Practices on Transparency in Monetary and Financial Policies

The report stated that Barbados' compliance with international standards in the onshore and offshore banking sectors was found to be generally high. However, some weaknesses in transparency and supervision in the insurance industry were noted. The issue of the definition of an insurance entity, licence classes and segregated cell companies were some of the concerns raised. The statutory requirement for the Supervisor of Insurance to determine on a contract-by-contract basis whether or not a transaction met the definition of insurance was also found to be not feasible administratively. The 2004 International Business (Miscellaneous Provisions) Bill included an amendment to the definition of insurance that resolved this matter.

One of the most important recent legislative changes has been the replacement of the Offshore Banking (1979) Act with the 2002 International Financial Services Act (IFSA), which introduced new requirements and restrictions in relation to the regulation of international financial services from within Barbados. The new act also enabled businesses organised under the Societies with Restricted Liabilities Act Cap. 318B to be eligible to apply for an offshore banking licence.

The IFSA (2002-05), which has improved supervisory compliance in the offshore banking sector, complements the Financial Institutions (1996) Act, the KYC ('know your customer') Guidelines and the regulations on Asset Quality and Capital Adequacy. Furthermore, the Act embraces the Core Principles for Effective Banking Supervision issued by the Basel Committee on Banking Supervision in 1997.

More specifically, the Act includes provisions which:

1. Permit the Central Bank of Barbados to conduct onsite inspections of offshore banks. 
2. Permit entities other than those incorporated under the Companies Act, including societies with restricted liability, to be eligible for an offshore banking licence.

3. Remove the distinction between resident controlled and non-resident controlled international companies in determining capital, as done under the previous Act. (This distinction was inconsistent with the precepts of a single market and the requirement for non-discrimination based on nationality).

4. Make provision for the prescribing, through regulation, of capital adequacy ratios. Regulations are being drafted that will take into account the new Bank for International Settlements (BIS) Capital Accord as well as market risk.

5. Mandate offshore banks to have a physical presence. ${ }^{5}$

6. Raise the minimum capital to Bds $\$ 4.0$ million for entities that take deposits and Bds $\$ 1.0$ million for those that do not. (The Bds $\$ 4.0$ million is in keeping with the requirement for commercial banks under the Financial Institutions Act).

7. Limit a bank's exposure to a person or group to 25 per cent of stated capital and published reserves, for banks which accept third party deposits.

8. Restrict the ownership or control of a bank by any person or group to 10 per cent of stated capital, except in cases where the approval of the Minister is granted for higher amounts.

9. Allow the Central Bank to examine any company, where there is reasonable cause to believe that the company is engaging in banking business without a licence.

10. Permit the Central Bank to inspect the books of any holding company, parent company or any other company that holds shares in a licensee.

11. Allow the Central Bank to disclose information to any supervisory or regulatory authority of a financial institution in Barbados and the appropriate supervisory or regulatory authority of a financial institution of another country at the request of that authority, where there is a branch, holding company or affiliate of the licensee operating in that country.

12. Permit entities that engage in intra-group treasury management, by lending and investing funds received from members of the group and where the liability is contained within the group, to elect not to be licensed under the International Financial Services Act (IFSA).

13. Require the prior consent of the home regulator before a licensee can establish a branch or subsidiary in Barbados.

In addition, the IFSA allows for more effective monitoring of the activities of offshore banks, including the requirement for prior Central Bank approval for changes in a bank's ownership structure, its articles of incorporation and any reduction in its capital and allows the Central Bank to request meetings, where appropriate, with external auditors and annual meetings with the directors and management of offshore banks. 
The Exempt Insurance Act and the domestic Insurance Act establish capital requirements for a EIC/QIC (qualifying insurance company) based upon premium written. The Companies Act (Section 356.25 (b)) provides for the formation of segregated cell companies (SCCs), and during the last five years the legislation was amended to allow local insurance companies to conduct insurance business under an SCC. A 2004 amendment to the insurance legislation also requires EICs on conversion to a qualifying insurance company to pay income tax on an ongoing, forward basis and not retroactively as has been in the past.

\section{Going forward}

The international investment and financial services community is rapidly improving standards of regulation and supervision in response to growing concerns over money laundering and international crime. With the international business sector identified as a key area for potential growth in Barbados, continued improvements in regulation and supervision in response to growing concerns over money laundering and international crime is critical. The objective is to attain international best practice in all areas of international financial activity, but in a rapidly changing environment this is especially challenging for small resource-constrained economies like Barbados.

Fear of being blacklisted, with the potentially damaging effect on business in the sector, has prompted governments to expeditiously attempt to meet the requirements set out by the various international agencies. While acknowledging the importance of these initiatives, small developing countries like Barbados continue to be challenged by the level of resources required to implement them. However, Barbados is well aware that the costs of ineffective regulation and supervision, which could result in loss of reputation through potential sanctions and advisories from other jurisdictions, are likely to be far greater than the costs associated with achieving and maintaining an effective level of supervisory oversight.

Notes

1. In 1999, the FATF embarked on a project known as the Non-Cooperative Countries and Territories Initiative. It defined criteria by which a jurisdiction could be deemed 'non-cooperative' and, after investigating 31 countries, the FATF cited 15 jurisdictions, which it considered to possess serious, systemic, money laundering problems. Five CARICOM member countries appeared on this 'blacklist': the Bahamas, the Cayman Islands, Dominica, St. Kitts and Nevis, and St. Vincent and the Grenadines. Other Caribbean countries were eventually dropped from the initial pool of 31 suspects, but were asked to tighten up their practices. These included Antigua and Barbuda, the British Virgin Islands, and St. Lucia. In June 2001, the FATF released a second list of 'non-cooperative' countries. Four countries were eventually dropped, but six more were added. The Bahamas and the Cayman Islands were both removed, and in September 2001 Grenada was added.

2. See Egmont Group website: http://www.egmontgroup.org/ [accessed 15 February 2008].

3. Barbados is also a member of the Caribbean Association of Regulators of International Business (CARIB) formed by the members of the Caribbean Community to establish, in a precise and systematic forum, strategies which convey CARICOM's position on the G7's 
continued attacks on Caribbean offshore financial centres (OFCs). CARIB's work programme consists of maintaining the integrity and transparency of international business transactions; increasing supervision of internationally mobile capital; ensuring appropriate standards and systemic stability; and enacting any other necessary financial intelligence activity. To perform its duties, CARIB is expected to foster a close relationship with the national authorities, since they will be the ones to negotiate with the G7 countries.

4. See CFATF website: http://www.cfatf.org/ [accessed 15 February 2008].

5. Defined as having at least one director who is a citizen of Barbados and who resides in Barbados. 